\title{
ВОПРОС О ПОВЫШЕНИИ В ЧИНЕ ПРЕДСТАВИТЕЛЕЙ КОМАНДНОГО СОСТАВА НИЖЕГОРОДСКОГО ОПОЛЧЕНИЯ В СЕНТЯБРЕ - ДЕКАБРЕ 1812 Г.
}

\section{THE QUESTION OF RAISING THE RANK OF REPRESENTATIVES OF THE COMMAND STAFF OF THE NIZHNY NOVGOROD MILITIA IN SEPTEMBER - DECEMBER 1812 \\ D. Nikolaev \\ F. Dorofeev}

Summary: in this article, on the basis of archival materials of the Central Archive of the Nizhny Novgorod Region (TSANO), the issues of raising the rank of representatives of the command staff of the Nizhny Novgorod militia formed in the era of 1812 are considered. $0 n$ the basis of the office documentation, information is provided on the numerical and personal composition of persons submitted for military ranks, as well as data on specific ranks and some other features of obtaining ranks in the context of the formation of the Nizhny Novgorod militia of 1812.

Keywords: Patriotic War of 1812, Nizhny Novgorod militia in 1812, marching march, weapon, equipment, financial assistance.

\author{
Николаев Дмитрий Андреевич \\ К.и.н., дочент, Нижегородский государственный \\ университет им. Н.И. Лобачевского \\ dmnikolaeff@mail.ru \\ Дорофеев Федор Александрович \\ К.и.н., дочент, Нижегородский государственный \\ университет им. Н.И. Лобачевского
}

feddor70@mail.ru

Аннотация: В данной статье на основе архивных материалов Центрального архива Нижегородской области (ЦАНО) рассматриваются вопросы о повышении в чине представителей командного состава нижегородского ополчения, формируемого в эпоху 1812 г. На основе делопроизводственной документации приводятся сведения о численном и персональном составе лиц, представляемых к воинским званиям, а также данные о конкретных чинах и некоторых иных особенностях получения чинов в контексте процесса формирования нижегородского ополчения 1812 г.

Ключевые слова: Отечественная война 1812 г., нижегородское ополчение 1812 г., походный марш, оружие, снаряжение, материальная помощь.

номочных структур [15, с.217], созданных специально для этой цели, особо выделялись, по своему значению и функциям, комитеты пожертвований [5, с.95] и вооружения [13, с.58]. Обмундирование [14, с.58], снаряжение $[12$, c.39] и даже вооружение [10, с.75] ополчений той поры осуществлялось за счет «отдатчиков ратников», т.е. помещиков [11, с.345], либо мещанских сообществ [16, с.35]. Все полки нижегородского ополчения входили в состав так называемого III ополченского округа (вместе с ополчениями казанским, вятским, симбирским, пензенским и костромским) [7, с.368] под предводительством генерал-лейтенанта П.А. Толстого [8, с.67]; начальником же нижегородского ополчения являлся князь Г.А. Грузинский.

Уже в процессе первоначального формирования полков, набора и обучения рядового состава, в сентябре-декабре 1812 г. появились первые претенденты на повышение в звании из среды офицеров, унтер-офицеров и подпрапорщиков, по поводу которых на имя Грузинского писали представления командиры полков. Командир 1-го полка Каратаев хлопотал о повышении в звании подпрапорщика П. Ключарева [20, л.3], а также о материальном поощрении «отставных военнослужителей» С. Сурина, Н. Попова и В. Жукова [20, л.14] за успехи в обучении ратников, одному из которых, Н. Попову, 
был предложен (по желанию) и следующий чин [20, л.20]. Командир 2-го полка Ровинский, «по недостатку офицеров», просил повысить в чине (до звания портупей-прапорщика) [20, л.1] подпрапорщика щербакова 3-го за «успехи» в «препровождении ратников» из г. Горбатова (поскольку никто из них не заболел и не сбежал (!)) [20, л.1], а также повысить до должности сотенного начальника пятидесятного начальника Зверева 1-го за его «особенное прилежание и способность» $[20$, л.9]. Князь Звенигородский (командир 3-го полка) отметил «хорошее поведение» и «рачительность» портупей-прапорщиков И. Бренделя и А. Еропкина, а также подпрапорщиков В. Зубова и Н. Чумичева, предложив «произвесть их» В пятидесятные начальники [20, л.16]; командованием этого же полка к следующим званиям были представлены «отлично усердные ... из дворян подпрапорщики» Сафонов, Костин и Нефедьев [22, л.18]. Командование 4-го полка рекомендовало на новые должности: пятидесятных Степанова [20, л.2], Шебалина («оказал особенные способности и примерное поведение» [20, л.4], Пантусова («по отличному усердию и способности к службе») $[20$, л.7] и Мещеринова («замечен ... за отличное усердие к службе») [22, л.22]; подпрапорщиков Демаре и Германа 1-го, (выполнявших «все обязанности с отличной ревностию» $[20$, л.5]), а также командиров батальонов: коллежского асессора Стремоухова [20, л.31], гвардии штабс-капитана Болтина и капитана Белавина [20, л.30]. В 5-м полку начальственными представлениями к новым должностям были рекомендованы портупей-прапорщики Ушаков 2-й, Чемоданов и подпрапорщик Москотиньев [20, л.21]. Командир конного полка Козлов просил о новом звании (юнкера) для «вольноопределяющегося урядника Николая Чугунского» [20, л.32].

Поощрения многих представителей командного состава ополчения были вызваны не только их объективными заслугами в деле формирования и обучения личного состава, но и необходимостью срочного повышения воинского статуса достойных командиров (в условиях нехватки офицерского состава) в целях передачи им командования над более крупными полковыми подразделениями в преддверии скорого начала военного похода.

В процессе формирования и действий нижегородского ополчения многие офицеры, ранее служившие «в гражданской службе» (а их в ополчении было большинство), получали, согласно указам Правительствующего Сената, следующие чины (по гражданской же службе) по выслуге лет, либо в силу каких-то особых обстоятельств. Несмотря на то, что они, формально, были уволены с прежней службы, в ополчении действовал «паритет» гражданских и военных чинов, а значит, соответственно возрастал и воинский статус повышаемых в гражданском чине. Новый чин - губернского секретаря - получили: А. Литвинов, А. Павлов, С. Постушенков, Н. Мещеринов, А. Панов [21, л.1-27]; коллежского секретаря - А. Богородский, С. Панов, П. Филисов, Дмитриев [21, л.1-27]; коллежского регистратора - А. Михайлов, П. Пирожков, П. Плешивцов, П. Колосовский, В. Ермолаев [21, л.1-27]; надворного советника - Н. Чичерин [21, л.27]. За «произведение» в новый чин и выдачу нового «патента» (т.е., свидетельства о наличии чина - авт.) со всех перечисленных лиц были вычтены деньги в казенную палату. По поводу вычетов с П. Филисова и П. Плешивцова командир 2-го полка полковник А.П. Ровинский обратился с просьбой к командованию ополчения о постепенных и меньших вычетах с этих офицеров ввиду получаемого ими небольшого жалованья, а именно: «... вычитать только третью часть требуемых с них денег, потому, что по малому жалованью их и по бедности не осталось бы им чем себя содержать ... сделать соразмерный вычет ... » $[21$, л.27]. Присвоение новых чинов и званий представителям командного состава нижегородского ополчения (еще до участия в боевых действиях) было вполне логичным шагом как фиксирования должной выслуги лет (по гражданской службе) и получения, в связи с этим, очередного чина, так и необходимой мерой по повышению воинского статуса некоторых представителей командного состава ополчения.

\section{ЛИТЕРАТУРА}

1. Грубов В.И., Николаев Д.А. Вопросы архивоведения и источниковедения в высшей школе//Отечественные архивы. 2018. №1. С.116-117

2. рубов В.И., Николаев Д.А. Вопросы архивоведения и источниковедения в высшей школе//Отечественные архивы. 2019. №2. С.129-131

3. Дорофеев Ф.А., Николаев Д.А. Особенности формирования офицерского корпуса в нижегородском ополчении 1812 г.//Вопросы истории. 2020 . №1. C.121-128

4. Дроздов Ф.Б., Николаев Д.А. Народное ополчение 1812 г. и общественный договор//Вестник Нижегородского университета им. Н.И. Лобачевского. 2012. №6 (3). C.95-99

5. Егоров Г.В., Николаев Д.А. Формирование «подвижного магазейна» по снабжению армии в Нижегородской губернии в 1812 г.//Гуманитарные и социально-экономические науки. 2017. №5 (96). С.95-98

6. Кауркин Р.В., Дроздов Ф.Б., Николаев Д.А. Отечественная война 1812 г. Нижегородское ополчение и его участие в заграничных походах 1813-1814 гг. Н. Новгород: НО ИРИ, 2012. 158 с.

7. Народное ополчение в Отечественной войне 1812 года. Сборник документов /Под ред. Л.Г. Бескровного. М.: Изд-во АН СССР, 1962.548 с. 
8. Николаев Д.А. Добровольцы в нижегородском ополчении 1812 г.: исторические реалии и историографические мифы//Вестник Нижегородского университета им. Н.И.Лобачевского.2018. №2. С.67-77

9. Николаев Д.А. Заболеваемость офицеров нижегородского ополчения 1812 г. (по материалам официального делопроизводства начала XIX века)// 0боронно-промышленный комплекс России: исторический опыт и современные стратегии. Сборник материалов II Всероссийской научно-практической конференции. 2017. С.96-99

10. Николаев Д.А. Как и чем вооружалось нижегородское ополчение в 1812 году//Военно-исторический журнал. 2019. №2. С.75-79

11. Николаев Д.А. Комплекс документов по вопросам продовольственного и вещевого обеспечения нижегородского ополчения 1812 г.//Торговля, купечество и таможенное дело в России в XVI - XIX вв. Сборник материалов Четвертой международной научной конференции. Редактор-составитель А.И. Раздорский. Редколлегия: В.Н. Беляева [и др.]. 2018. С.345-349

12. Николаев Д.А. Материалы официального делопроизводства по вопросам продовольственного и вещевого обеспечения нижегородского ополчения 1812 г.//Вопросы архивоведения и источниковедения в высшей школе. Сборник статей участников XVI Региональной научно-практической конференции. Под редакцией В.И. Грубова, А.А. Исакова. 2019. С.39-43

13. Николаев Д.А. Некоторые аспекты развития военного производства Нижегородской губернии в начале XIX века (на примере вооружения нижегородского ополчения 1812 г.)//0боронно-промышленный комплекс России: исторический опыт и современные стратегии. Сборник материалов II Всероссийской научно-практической конференции. 2017. С.58-62

14. Хвостова И.А., Николаев Д.А. Инспекторский смотр обмундирования и снаряжения нижегородского ополчения в 1812 г.//Современная наука: актуальные проблемы теории и практики. Серия: Гуманитарные науки. 2017. №12. С.58-61

15. Хвостова И.А., Николаев Д.А. Логистические особенности обеспечения нижегородского ополчения 1812 г. на начальном этапе его формирования (сентябрь - октябрь 1812 г.)//Вопросы истории. 2020. №2. С.217-224

16. Хвостова И.А., Николаев Д.А. Страницы истории нижегородского ополчения 1812 г.: проблема «лишнего» оружия//Современная наука: актуальные проблемы теории и практики. Серия: Гуманитарные науки. 2019. №9. С.35-37

17. Хвостова И.А., Николаев Д.А. «. . Упражняются... . пьянстве и буйстве. . .»: формирование и девиантные особенности походного марша 3-го полка нижегородского ополчения (сентябрь 1812 - июнь 1813 гг.)//История: факты и символы. 2019. №4 (21). С.27-36

18. Хвостова И.А., Николаев Д.А. Формирование и походный марш 5-го полка нижегородского ополчения 1812 г. (сентябрь 1812 - апрель 1813 гг.)//Гуманитарные и социально экономические науки. 2019. №3 (106). С.98-103

19. Хвостова И.А., Николаев Д.А. Формирование и походный марш конного полка нижегородского ополчения 1812 г. (сентябрь 1812 - февраль 1813 гг.)// Гуманитарные и социально экономические науки. 2018. №2 (99). С.115-119

20. Центральный архив Нижегородской области (ЦАНО), Ф.1822, 0п.1, Д.54

21. ЦАНО, Ф.1822, 0п.1,Д.75

22. ЦАНО, Ф.1822, ОП.1, Д.119

( Николаев Дмитрий Андреевич (dmnikolaeff@mail.ru), Дорофеев Федор Александрович (feddor70@mail.ru). Журнал «Современная наука: актуальные проблемы теории и практики» 